\title{
UNDERSTANDING GRECO-ROMAN DERIVATIVES: AN IMPLICATION FOR LEARNING ANGLICIZED CONCEPTS
}

\section{Muhammmad \\ Muhammad Suleiman' \\ Shitu Sani ${ }^{2}$ \\ Shettima Mamman \\ Adam $^{3}$}

'Department of Home \&

Rural Economics

School of Rural Technology \&

Entrepreneurship

Development, Rano Kano

State Polytechnic

${ }^{12}$ M. A. Education,

Department of Education

Lovely Professional

University, Phagwara, Punjab

\section{Alamat Korespondensi}

'muhddkd@gmail.com

2shitusanil968@gmail.com

3shettimamammanadam56@g

mail.com

\section{ABSTRACT}

Education, in its true sense, is not synonymous with literacy, as it is very much linked to the gathering of information and to the application of effective solutions to the myriad problems of global society. The nuanced nature of the study of science in particular and humanities in general requires a great deal of effort from students, ranging from practical, field trips, excursions, records to the comprehension of derivatives and the technical sense of terms used in various fields of study, with particular reference to the unique nature of Greco-Roman words, which are typically subject to rotation by students. This gulf culminates in the student's acquisition of a lower level of learning and the deprivation of the reflective level of thought that contemporary society requires. In this paper, an attempt has been made to analyze the root derivatives of a variety of concepts and their technical interpretations, as applied in a number of different disciplines of science and humanities, in order to promote a deeper understanding of the definitions of technical words.

Keywords: Greco-Roman, Anglicized, Science, Humanities, Education, Teaching

\section{INTRODUCTION}

Technology has affected educational environments significantly and continues to do so although potential disadvantages or limitations of online learning have been identified. Research has indicated drawbacks to online learning, including learner isolation (Brown, 1996); learner frustration, anxiety, confusion (Hara \& Kling, 2000); and the need for more discipline, selfmotivation, and time commitment to learning (Golladay, Prybutok, \& Huff, 2000; Serwatka, 2003). The U.S. Department of Education (2009) reported that online learning offered an advantage over traditional classroom instruction. According to the findings of an analysis conducted by the U.S. Department of Education, students who took all or part of their classes online performed better than those in traditional face-to-face instruction did. Furthermore, students in blended (or hybrid) classes performed better than those in purely online courses. The investigator concluded that instruction using technology is more effective compared to purely traditional face-to-face instruction because increased time on task and learner reflection in online learning environments through interactions with media help students reach higher levels of achievement (Gan 20I I).

Nevertheless, effectively giving instructions related to critical languages (less commonly taught languages such as Japanese and Arabic) that do not have commercially developed, onlinebased textbook packages, including class schedules, materials, and assessment, is challenging in distance learning courses aimed at providing quality instruction equal to that of faceto-face classes. Currently, only a few instructors in the field of Japanese language education have developed curricula for teaching distance learning courses in the United States; therefore, one of the aims of this article is to show an example of the distance learning course developmental processes. This article focuses on methods to bridge the distance-separating student from the student as well as student from instructor to enhance the success of a diverse group of students in a virtual classroom. The first part discusses how a first-year Japanese distancelearning course was planned. The second part describes how the distance-learning course was 
managed to develop basic communicative skills and global views simultaneously using the synchronous and asynchronous online components of Blackboard. Finally, distance learning students' feedback from a course survey is reported (Gan 20II).

The Late Antiquity experienced profound cultural and social change: the political disintegration of the Roman Empire in the West, contrasted by its continuation and transformation in the East; the arrival of 'barbarian' newcomers and the establishment of new polities; a renewed militarization and Christianization of society; as well as crucial changes in Judaism and Christianity, together with the emergence of Islam and the end of classical paganism. This series focuses on the resulting diversity within Late Antique society, emphasizing cultural connections and exchanges; questions of unity and inclusion, alienation and conflict; and the processes of syncretism and change. By drawing upon several disciplines and approaches, this series sheds light on the cultural and social history of Late Antiquity and the greater Mediterranean world (Cilliers n.d.), (Edition 1988).

Much has been written on the techniques of magic working in antiquity. Great advances have been made in the understanding of how spells written on lead, papyrus, or a sherd of pottery was composed, what kinds of formulae were employed in them, what symbols were inscribed on magical amulets and what manner of devices were worn to ward off evil forces. The belief systems that informed the practices of the more sophisticated and educated sorcerers of the ancient world have been studied, in particular their debt to Platonism and its strange offspring, Neopythagoreanism and Gnosticism (Dickie 2003). However, little attention has been paid to the men and women who were believed by their contemporaries to be expert in magic or whom themselves professed expertise. There has been no study of who it was to whom men and women went for help if they wanted to put a spell on someone, to have a spell taken off, to nullify the effects of an ominous dream, or to have a child cured of some inexplicable illness by incantations and amulets. Nor has there been any comprehensive treatment of the educated men who in their fascination with magic made collections of magical lore or who engaged in magical rituals to effect a union with the divine or with the more mundane goal of altering the course of nature. Nor yet again has the magicworking of the holy men who wandered from community to community (Dickie 2003), (Schools 2009).

\subsection{The Theoretical Background of Roman Empire}

a) Online Learning Community: Both individual and social learning processes affect learning outcomes. According to Jonassen, Peck, and Wilson (1999), the five attributes of meaningful learning are "active, constructive, intentional, authentic, and cooperative" (p. 7). In particular, cognitive constructivism claims that individual construction of knowledge is discovered through interaction in the environment (Bonk \& Cunningham, 1998). From a social constructivist perspective, "Meaning making is a process of negotiation among the participants through dialogue or conversations" (Jonassen et al., 1999, p. 5). Thus, from the constructivist's viewpoint, online learning communities in distance learning classes play important roles as networks of social relationships in which engagement and interaction are critical to the learning environment (Gan 20II).

b) Development of Intercultural Abilities: Using online components that emphasize social formation, thereby enhancing global views and cross-cultural understanding, is necessary for distance learning students who are learning foreign languages as culture has been emphasized as the core of the foreign language curriculum in such publications as Standards for Foreign Language Learning in the 2 Ist Century (National Standards in Foreign Language Education Project, 1999). According to Byram's (2000) definition (Byram, 1997; Byram \& Zarate, 1997), intercultural competence (ICC) refers to the ability to perceive relationships between different cultures both internally and externally. "Intercultural" reflects the view foreign- language students must gain insight into their native culture as well as the target culture to mediate and explain differences. In 
addition, these students need to become aware of the meeting of cultures that occurs in communication using the learned foreign language (Kramsch, 1993). Intercultural competent people should be able to mediate either for themselves or for other people by interpreting each in terms of the other. They can critically or analytically understand their own and other cultures through conscious processes based on their own perspectives (Gan 20I I).

c) Redesign of Course Curriculum: Despite the fact that some remarkable software (e.g., Natural Language Processing techniquesparsing) can analyses whether students' answers are correct and can provide flexible feedback based on students' input, this capability tends to be limited to the sentence level. For students enrolled in the present distance-learning course to further develop language skills beyond the sentence level, the curriculum of the distance-learning course discussed in this article was developed carefully. This section describes how the syllabus of this distance learning course was developed using the same textbook, An Integrated Course in Elementary Japanese: Genki I, (Banno, Ohno, Sakane, \& Shinagawa, 1999) and workbook as an in-class course but incorporating the considerations of how distance between the students and their instructor was bridged effectively to foster autonomous learning abilities (Gan 20ll), (Gascoyne et al. 1997).

d) Course Redesign: Learning autonomy is one of the key elements to success in distance learning and self-instruction. Autonomous learners transcend the barriers between learning and living, according to the definition of autonomous learning in the fields of educational psychology, educational theory, and curriculum development (e.g., Barners, 1976; Bruner, 1966; Illich, 1979; Rogers, 1983); namely, autonomous learners tend to integrate what they learn in the formal context of the classroom with what they already know through experiences in real-life situations (Little, 1995) (Gan 201I), (Gascoyne et al. 1997).

\subsection{Greco-Roman Schooling}

The Greco-Roman school exerted a profound influence on ancient culture as it evolved between the 5th century b.c. and the 3d century a.d. It first appeared in ancient Athens, developed with the early sophists, and then, thanks to Plato and especially to Isocrates, assumed a form that it kept through the whole Hellenistic period. The Romans had only to adapt an already perfected institution to their own use. As they expanded, they introduced it into all sections of the empire (Schooling 2020), (Ages et al. 2020), (Roots and li n.d.), (Mac Sweeney 2019).

\section{I Christianity and the School}

Two possible positions confronted each other from the beginning: to reject the school or to compromise. Opposition between Christian principles and those of the school of antiquity seemed absolute. Christianity as a religious way of life apparently had nothing in common with Hellenism. "Where is the 'wise man'? Where is the scribe? Where is the disputant of this world? Has not God turned to foolishness the 'wisdom' of this world?" Paul had asked (I Cur I.20) (Schooling 2020), (Ages et al. 2020).

\subsection{Christian Classical Culture}

Even before the undertaking of the two Apollinaire has, some learned Christians decided that the language of the Bible was too crude and attempted to provide their contemporaries with the sacred texts in classical form. The Spanish priest Juventus c. 330 put the Gospels into verse so that the content of the divine message could be remembered better. The Roman Proba succeeded in translating biblical stories in hemistiches of Vergil. In Gaul, Cyprian offered a versified translation of the Heptastich. His exploit was repeated by the rhetor Marius Victorious in the 5th century and by avitus of vienne in the 6th. Christian poetry of the fourth and fifth centuries flowed effortlessly in the classical mold giving new life to a literary genre that had been dying out (Schooling 2020), (Lampe 2016).

\subsection{Christian Oratory}

Sacred preachers also availed themselves of the devices of the traditional rhetoric when they presented their message. In the East a renaissance of pagan eloquence had a great influence in learned Christian circles. john Chrysostom, student of Libanius the rhetor of Antioch, Basil of Caesarea and Gregory of 
Nazianzus, former students at the school of Athens, did not forget the lessons of their masters. Gregory of Nazianzus, apropos of the school law of Julian, cried: "I have given up riches, nobility, glory, power, but I hold fast to eloquence" (Or. 4.100, Patrologia Graeca 35:636). In the West in the sermons of St. Ambrose and St. Augustine, appear the topoi (common places) dear to rhetors. To be sure, the Fathers of the Church as a rule avoided the bad features of rhetoric, but many preachers of the period sought to please rather than to instruct and courted applause in their own churches (Schooling 2020).

\subsection{Christian Learning.}

The presence of Christian professors in the school of antiquity not only enabled them to present Christian thought in classical guise, but offered them the means to construct a basically Christian scholarship. Following principles proposed by Origen, they saw in the program offered in the school a propaedeutic for the scientific study of Holy Scripture. In his Admonitions to Young Men on the Profitable Use of Pagan Literature, Basil of Caesarea suggested that "as dyers begin by exposing an object to be dyed to certain preparations, if we wish our idea of the good to be indelible, we will demand of these external sciences a preliminary initiation whereby we can better understand the holy teachings of the mysteries." Clearly, one had to know how to choose what was good for the soul and reject what was harmful. Jerome took the same position: "When books of worldly wisdom come into our hands, if we find something useful we take it over for our doctrine, but what is in excess or alludes to idols, love, or world matters we cut out" (Epist. 21.13.6). Jerome, caught between his classical education and his monastic vocation, did not want to be "more Ciceronian than Christian." While he cautioned his correspondents against the dangers of profane literature, he realized nevertheless that neither Christians nor clerics could be ignorant of secular branches of knowledge. He compared this learning to the comely captive that the Israelite could marry after shaving her head and paring her nails (Epist. 21.13.5, 70.2.5) (Schooling 2020).

\section{A) School organization:}

The school of the magister ludic or literato (elementary school) accepted a child at seven and taught him to read according to the analytical method (letters, syllables, words). First, he read short moral texts, fables, or the distichal catonis. At the same time, he learned to write by copying words on wax tablets. Then he was taught basic arithmetic, in particular how to calculate on his fingers (digital computation). The techniques of instruction at this stage were rather basic and the rod was not spared (Augustine, Conf. I.9.14-15) (Schooling 2020), (Ages et al. 2020).

Among the Hebrews: Poor children helped their parents with their work and girls helped with household chores. Higher education was given by priests and scribes in the prophets' schools. The first elementary schools and the idea of free and obligatory schooling are introduced (Schooling 2020), (Ages et al. 2020).

a) In Athens: Schools for grammar and music are private with teachers competing for students. Schools run by rhetorical orators and sophists taught public speaking and philosophy (Ages et al. 2020).

b) In Rome: Those with enough money called on slave-tutors and on private schools (Ages et al. 2020).

\section{B) Learning contents}

The school at Charlemagne's palace follows classic tradition, in line with the Greeks and Romans. In the episcopal schools (primary schools for all classes of society), basic reading, writing and counting with chips were taught, along with some notions of Latin (Ages et al. 2020).

In the colleges, young people were taught Latin, poetry, sciences, public speaking, and law. The Muslims and Persians inspired the Knights' education, established following the crusades. It consisted of physical education, song, music and good manners. The concept of honor was particularly meaningful. Universities taught the Seven Liberal Arts: the "tritium" (grammar, rhetoric and logic) and the "quadrivium" (arithmetic, music, geometry, astronomy). Guilds offered professional and moral instruction (Ages et al. 2020). 
Among the Hebrews: Education is initially the responsibility of families and involved reading, writing and the history of their religion. It was based on sacred texts. Mathematics, astronomy, literature and geography were taught at more advanced levels (Schooling 2020), (Ages et al. 2020).

a) In Sparta: Education in Sparta aimed to train and build brave, strong and patriotic soldiers. It consisted in training for the hunt and in physical and military exercises (Ages et al. 2020).

b) In Athens: Depending on the social status, the level of instruction was not the same. The son of an artisan would simply learn to read, write and count. The wealthier population would receive a complete education in order to become real citizens. Education aimed to harmonize body, art and soul (Ages et al. 2020).

c) In Rome: Education is military, patriotic and utilitarian: reading, writing, calculus, and military training and of course dedication to the motherland. Thereafter, grammar and rhetoric become more and C) Teachers: more present at school (Ages et al. 2020).

Among the Hebrews: Teachers were well regarded because the Talmud placed them above the father (Ages et al. 2020).

a) In Athens: Until the age of 5 or 6 children were educated by women. When they reached 7 years of age, their education was provided by teacher-slaves (Ages et al. 2020). The slave would accompany the children to their lessons and insure that they behaved. A grammarian taught reading, writing, mythology, calculus as well as drawing and geometry. A citharist (player of zither) taught music and a palestra taught gymnastics (Schooling 2020), (Ages et al. 2020).

b) In Rome: Military and religious education was given in the family. From the age of 12, a grammarian taught, grammar and literature in Greek, followed by in Latin. From 17 years of age, a rhetorical orator prepared them for public speaking (Ages et al. 2020).

\section{D) Teaching Methods:}

Among the Hebrews: Study of sacred texts with teaching based on discipline, rituals, music and dance (Schooling 2020), (Ages et al. 2020).

a) In Sparta: Physical blows and suffering aimed to harden children (Ages et al. 2020).

b) In Athens: Children memorized and recited excerpts from Aesop and Homer. Rituals, dances, singing, theatre, games and parades were also a part of their education (Ages et al. 2020).

c) In Rome: Discipline, respect for power and imitation were important aspects of education (Ages et al. 2020).

\section{E) Specificities:}

In Sparta: Girls and boys received similar education, which was aimed at preparing them for being of service to the community. Children belonged to the state (Schooling 2020), (Ages et al. 2020)..

a) In Athens: Education aimed at giving both a sense of order and of beauty. Professional education was limited since the large number of slaves fulfilled most needs. Manual labor was scorned and only girls with a high-born background were taught to read and write (Ages et al. 2020)..

b) In Rome: Girls were limited to being educated within their families. Greek was progressively replaced by Latin (Ages et al. 2020).

\subsection{The Studies in the Schools}

To understand the school of antiquity now during the $3 \mathrm{~d}$ century when Christians began to take an interest in it, one must distinguish developments in the West from those in the East. Studies in Roman schools were essentially literary and oratorical, diverging from the Greek tradition, which placed a high value on the liberal arts, the three literary disciplines (grammar, rhetoric, dialectic) and the four sciences (arithmetic, geometry, music, astronomy). These seven branches of learning were introductory to the supreme art, philosophy. Among the Romans, however, scientific and philosophical studies gradually disappeared as the knowledge of Greek came to be restricted to elite. In the East, on the other hand, the philosophical 
tradition continued. There, the student learned logic, physics, and especially ethics that prepared him to attain the supreme good and happiness, the goal of all his studies. Under the Later Empire, however, the school was employed to produce officials for the constantly increasing governmental bureaus, and the state became more and more interested in the municipal schools, favoring them even in the farthest reaches of the empire. The more totalitarian the state became, the more it encroached in this area. After Julian the apostate, only persons approved by the municipal council, or even the emperor, could teach. In the 5th century Theodosius II founded an imperial university in Constantinople and gave it a monopoly in higher education (Schooling 2020), (Ages et al. 2020).

Early in its development, Christianity was faced with a dilemma. Could the Church ignore this Greco-Roman school and develop its own religious schools, as the Jews had done with the Synagogue? Or would they try to enter into the school and Christianize it? Would they find another solution? The matter was important, for on the decision of the Church would depend the future of Mediterranean culture (Schooling 2020), (Ages et al. 2020).

\subsection{Rejection}

At first the wisdom of the Greeks was considered incompatible with the true wisdom of the Gospel, and the early Christians who were regarded with contempt as "barbarians" by learned pagans took great pride in that epithet (Tertullian, Test. anim. I). The Christian seeking an education had no need to go to the school of the pagans. The third-century didascalia apostolorum represents the attitude of the early Christian communities: "Do not even touch the books of the gentiles. What have you to do with these alien words and laws, or the false prophets who so easily bestow error on inconstant men? What do you lack in the word of God that you should turn to pagan fables? If you wish to read history, you have the Book of Kings; if you need philosophy or poetry, you have the
Prophets.... If you desire songs, you have the Psalms; if you wish to know the beginning of the history of the world, you have Genesis.... Abstain therefore absolutely from all these profane and diabolical works" [1.6, Latin fragment, ed. Connolly (Oxford 1920) 13]. The monks, for whom true philosophy was not to be learned in the school but in solitude, by meditating on sacred writings, originally adopted this rigorist idea of Christian culture,. What would the Christian student find at the pagan school but immorality in the legends of mythology, and idolatry in the cult of false gods? As John Chrysostom said, "Why send Christian youths to masters where, before the art of speaking, they will learn evil?" (Adv. opp. vitae monast. 3.95) (Schooling 2020).

\subsection{The Dialogue Begins}

If Christianity had developed apart from the Hellenic world, all Christians would probably have taken the position of the rigorists. However, the Gospel had been written or translated into Greek, and borrowed much of its vocabulary from Hellenism, beginning with the all-important concept of the logos ( In I). Thus, Christianity simply could not escape the influence of the cultural atmosphere in which it developed. From the second century, learned men who had been graduated from the school of antiquity had been turning to the new religion. In their writings, they could not abandon their early training. In his Dialogue with Tryphojustin martyr (d. c. 163) recalls how he arrived at the knowledge of the God of the Gospel by stages, following the development of pagan philosophy, and in his Apologies, he proves that Christianity provided answers for the questions posed by Greek thinkers. The Christian apologists (see apologists, Greek), who created the first Christian philosophy, took over many ideas from ancient philosophies, especially from Stoicism (Schooling 2020).

\subsection{Gain Knowledge and Understanding of Greco-Roman Culture}

Formulating an understanding of the perspectives of the Greeks or Romans through their practices and through their products is key to an understanding of their culture. The focus in Goal 
2 is on the ability of students to hear (i.e., read) and see (in physical remains) the message of the Greeks or Romans. Their daily life, education, politics, history, philosophy, and religious practices tell students about their perspectives, revealed both in their literary products and in remaining artifacts. Literature, as well as nonliterary writing, is key to an understanding of culture; it is a product of the culture and a primary source for under- standing ancient practices (Gascoyne et al. 1997), (Gan 20I I).

Standard 2.1: Students demonstrate an understanding of the perspectives of Greek or Roman culture as revealed in the practices of the Greeks or Romans (Gascoyne et al. 1997).

\section{Sample Progress Indicators}

\section{Beginning}

- Students demonstrate a basic knowledge of the daily life of the ancient Greeks or Romans (Gascoyne et al. 1997).

- Students demonstrate knowledge of some famous Greeks or Romans and of selected facts of history and geography of the ancient world (Gascoyne et al. 1997).

\section{Sample Progress Indicators}

\section{Intermediate}

- Students demonstrate a knowledge of the daily life and thought of the ancient Greeks or Romans, gained in part from the Latin or Greek texts they read, and apply that knowledge to an understanding of Greek or Roman culture

- Students demonstrate a knowledge of the people and facts of Greek or Roman history and political life, gained in part from the Latin or Greek texts they read, and relate that knowledge to an understanding of Greek or Roman perspectives

- Students demonstrate knowledge of philosophy, religion, and the arts of the ancient Greeks or Romans, gained from their reading of Latin or Greek authors, and relate that knowledge to an understanding of Greek or Roman perspectives

\subsection{The Status of Classical Language Learning in the United States Today}

At the turn of the century-and the millennium - the teaching of classical languages continues to hold a vital place in American education. We are traditional, the inheritors of Preclear Athens of the 5th century B.C. and of Augustan Rome at beginning of the first millennium of this era; but we are innovative, timely and practical, prepared to enter a new millennium. Our appeal does not depend on political or economic interests, but rather on educational beliefs that do not go out of style (Gascoyne et al. 1997).

There are an estimated half million students in Latin classes in the United States today. Ancient Greek is standard in leading colleges and universities in the country; the more recent addition of courses in classical civilization, etymology, and mythology has increased the vitality of Greek and Latin as staples in the college curriculum. Continuing interest in GrecoRoman culture is paralleled by the continued vigor of Latin language study, in part, from the recognition that the study of Latin can be a very effective aid in improving language skills in English and in the subsequent learning of other foreign languages. As a corollary of Latin's resurgence, there is a growing need for a new generation of Latin teachers (Gascoyne et al. 1997).

The persistent popularity of Latin in the last two decades has also brought forth a spirited array of creative, exciting, and more effective teaching materials. Latin classrooms are increasingly lively and engaging. Students learn to read with an emphasis on authentic materials from the ancient world: its literature, graffiti, coins, and inscriptions. Students make connections from their reading to the other subjects they are studying in school and to the communities that surround them. They examine the products and practices of ancient peoples in the light of their own experiences and are challenged to make comparisons (Gascoyne et al. 1997).

\subsection{About Standards for Classical Language Learning}

The words, ideas, and culture of the ancient world are communicated to us in the writing and the archaeological remains of the people and their institutions. The ancient Greeks and Romans, breaking barriers of time and place, have 
communicated their message through the ages and continue to communicate to the modern world; we, in turn, communicate more clearly to each other in word, in practice, and in product as a result of that contact (Gascoyne et al. 1997). Standards for Classical Language Learning applies five goals of communication to a context appropriate for Latin and Greek (Gascoyne et al. 1997). The standards for classical language learning are organized within the five goal areas which make up classical language education: communication, culture, connections, comparisons, and communities (Gascoyne et al. 1997). Each goal is one strand in a fabric that must be woven into curriculum development at the state, district, and local levels. Each goal area contains two content standards. These standards de- scribe the knowledge and abilities students should acquire (Gascoyne et al. 1997).

\section{REFERENCES}

Ages, Middle, The Revival, An Encyclopaedic, and Humanistic Education. 2020. "Education in the Judea-Christian and Greco-Roman Traditions : From Family- Centred Education to the Teacher-Slaves Article Index." I-8.

Cilliers, Louise. n.d. Roman North Africa Environment, Society.

Dickie, Matthew W. 2003. Magic and Magicians in the Greco-Roman World.

Edition, Corrected. 1988. "Women in the GrecoRoman World." (Luke 2):33-48.

Gan, Zhengdong. 20II. "Theory and Practice in
Language Studies." Theory and Practice in Language Studies I(8): 194-205.

Gascoyne, Richard C., Martha Abbott, Z. Philip Ambrose, Cathy Daugherty, Sally Davis, Terry Klein, Glenn Knudsvig, Robert LaBouve, Nancy Lister, and Karen Lee Singh. 1997. "Standards for Classical Language Learning." 48.

Lampe, Peter. 2016. "Social Welfare in the Greco-Roman World as a Background for Early Christian Practice." Acta Theologica 2016:1-28.

Roots, Latin, and Part li. n.d. "Greek and Latin Roots: Part II - Greek."

Schooling, Greco-roman. 2020. "Greco-Roman Schooling Christianity and the School." I-6. Retrieved January 2, 2020 (https://www.encyclopedia.com/religion/ency clopedias-almanacs-transcripts-andmaps/greco-roman-schooling).

Schools, Southern African. 2009. "GRECOROMAN SCHOOLING." Association of Southern African Schools and Departments 17(I). Retrieved September 15, 2020 (https://www.encyclopedia.com/religion/ency clopedias-almanacs-transcripts-andmaps/greco-roman-schooling).

Mac Sweeney, Naoíse. 2019. "Claiming the Classical: The Greco-Roman World in Contemporary Political Discourse." Council of University Classical Departments Bulletin 48(May): $1-19$. 